\title{
From Whole Earth to the Whole Web
}

\section{Henry Lieberman}

$\mathrm{W}$ e're pretty damn lucky we got the Internet we did: a worldwide network in which almost anybody can read, publish, and program pretty much anything. It didn't have to turn out that way. It could have been dominated by a few corporations, spoon-feeding junk-food media to the masses, just like television. Or balkanized communications providers could have saddled users with deceptive charging schemes and stifled technical innovation, just like cell phones.

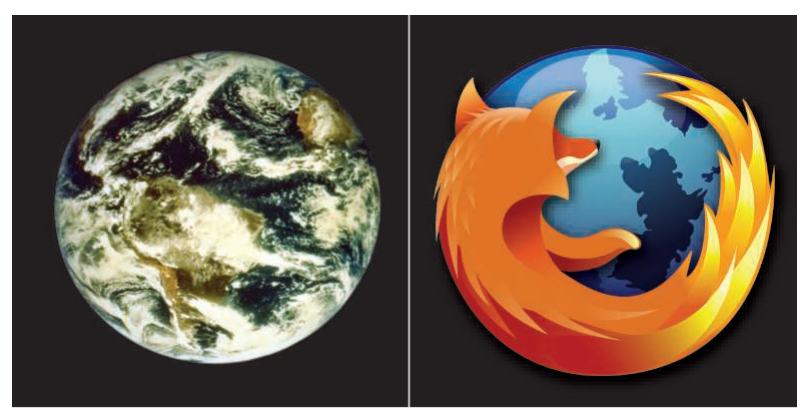

at one slice through this marvelous story. Unlike many other histories that focus on the technical innovators - the Vin Cerfs, the Tim Berners-Lees, the Alan Kays, the Marvin Minskys - this account focuses on a key player whose role was making the counterculturecyberculture connection: Stewart Brand. Brand's contribution was reporting on this phenomenon; theorizing about it; popularizing it; cheerleading for it; and organizing, networking, and providing resources for it. Brand articulated the unspoken consensus values of the communities. It's hard to say exactly what he did, but everybody knew him, and that sure helped.

Though the book has lots of personal details of Brand's life, it is not a biography. Rather, it focuses on events that swirl around him. It traces his involvement with 1960s communes and conceptual art

That we happened to get such an open network was a miracle. But it wasn't an accident. The technical community that built today's digital infrastructure did so around a certain set of cultural values, among them openness, sharing, personal expression, and innovation. These were core values of the early digital pioneers (the hackers), embodied in what we proudly call the "hacker ethic." Today, we take the digital revolution for granted and seldom appreciate to what extent these values were sparked by the 1960 s counterculture, which preceded the 을 digital revolution: counterculture begat cyberculture.

Because of the happy coinci-

From Counterculture
to Cyberculture
Stewart Brand, the
Whole Earth Network,
and the Rise of Digital
Utopianism
by Fred Turner
University of Chicago
Press, Chicago, 2006 .
353 pp. \$29, £18.50.
ISBN 9780226817415.
communities. The Whole Earth Catalog and magazines served as a kind of primitive "hardcopy Web" of resources that reflected the common values of both communities and led to Wired. The WELL, an early message board system, was an influential example, attracting both cyberculture and counterculture participants. Although a casual reader might be misled into thinking that the WELL invented today's virtual communities, blogs, and socalled Web 2.0, it was certainly a step toward these phenomena. Brand's Global Business Network, a consulting company, tried to make countercultural and cybercultural ideas accessible to high-level corporate planners.

The great thing about this book is that Turner (a former journalist now in the Department of Communication, Stanford University) really took the time to sweat the details. There are a myriad of fascinating little historical details that he dug up that will surprise and enlighten even the key players in the drama who pick up this book. He doesn't always get things right, though. I won't quibble with various inaccuracies from my personal knowledge but only say that it shouldn't be the only book you read on this subject. Sometimes Turner's account has that not-wrong-but-not-quite-the- whole-story feel of a tourist sharing cultural perceptions after reading a guidebook and a week's trip.

First of all, go back to at least some of the original sources. I fear younger readers might never have seen a Whole Earth Catalog. They may not get what the fuss is about just from reading Turner's descriptions and the book's fuzzy reproductions of two pages. Ted Nelson's Computer Lib/Dream Machines (1), dismissed by Turner in a single sentence, drew the counterculture-cyberculture connection even more explicitly than Whole Earth. Steven Levy's Hackers (2) is also a must. Brand's own short and inspiring "Spacewar: Fanatic Life and Symbolic Death Among the Computer Bums" (3) simply says it all.

Whereas Brand is all about enthusiasm, Turner's writing is in the dry and detached style of a sociology thesis. Brand is a terrific writer, but Turner is no Brand. So, bring your own enthusiasm to the book, from your own experience in the cyberculture, the counterculture, or both. But when you're ready to understand how that enthusiasm got us to where we are today, read Turner.

To get you started, I'll leave you with Brand's introduction to the "Fanatic Life" piece (3):

Ready or not, computers are coming to the people.

That's good news, maybe the best since psychedelics. It's way off the track of the "Computers-Threat or Menace?" school of liberal criticism but surprisingly in line with the romantic fantasies of the forefathers of the science such as Norbert Wiener, Warren McCulloch, J. C. R. Licklider, John von Neumann and Vannevar Bush.

The trend owes its health to an odd array of influences: The youthful fervor and firm dis-Establishmentarianism of the freaks who design computer science; an astonishingly enlightened research program from the very top of the Defense Department; an unexpected marketflanking movement by the manufacturers of small calculating machines; and an irrepressible midnight phenomenon known as Spacewar.

\section{References}

1. T. H. Nelson, Computer Lib: You Can and Must Understand Computers Now/Dream Machines: New Freedoms Through Computer Screens-A Minority Report (T. H. Nelson, Chicago, 1974).

2. S. Levy, Hackers: Heroes of the Computer Revolution (Doubleday, Garden City, NY, 1984).

3. S. Brand, Rolling Stone, 7 December 1972, pp. 50-58. 